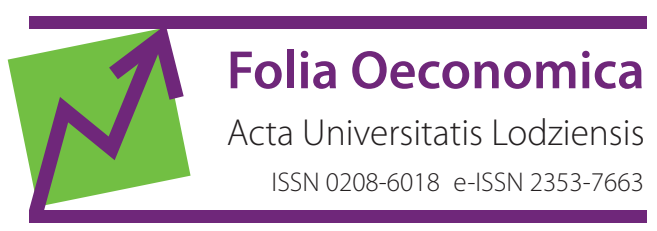

www.czasopisma.uni.lodz.pl/foe/

4(330) 2017

DOI: http://dx.doi.org/10.18778/0208-6018.330.01

\author{
Iwona Markowicz \\ University of Szczecin, Faculty of Economics and Management, Institute of Econometrics \\ and Statistics, iwona.markowicz@wneiz.pl
}

\title{
The Differentiation of Firm Survival Models in the Poviats of the Zachodniopomorskie Voivodeship
}

\begin{abstract}
The aim of the study was to construct models of firms' survival duration for individual poviats in the Zachodniopomorskie Voivodeship. The first stage was the calculation of the Kaplan-Meier estimator and the use of a test for the verification of similarities in the survival function for the analysed poviats. As a result, groups of poviats were created. The next stage of research was the construction of duration tables of the studied firms and an analysis of the intensity function of firms' liquidation for the poviats. The percentage of firms liquidated after two years of activity in different poviats (stage III) was presented. An analysis of correlation between the percentage of firms liquidated in the analysed period and the number of entities registered per 10 thousand of population in the poviats (stage IV) was also conducted. This study used data from the registry of REGON related to companies established in the Zachodniopomorskie Voivodeship in 2009-2011. These entities were observed till the end of 2013. The study results reveal the differentiation of firm survival models in the poviats of the Zachodniopomorskie Voivodeship. Five groups of poviats were distinguished and characterised.
\end{abstract}

Keywords: models of firms' duration, intensity function of firms' liquidation, poviats of the Zachodniopomorskie Voivodeship

JEL: C10, C14, C41 


\section{Introduction}

For the purpose of the survival analysis, parametric, semi-parametric, and non-parametric models are used. The construction of parametric models requires the adoption of a theoretical distribution of the examined variable (Gazińska, 2003; Frątczak et al., 2005), which is difficult in the case of studies on the duration of firms (Markowicz, 2012; Markowicz, 2014). Therefore, in this study, continuous-time non-parametric models were used: the Kaplan-Meier estimator, the duration table (intensity liquidation), and the Gehan test. Those methods were employed to model the survival time and find differences in the survival of firms in the poviats of the Zachodniopomorskie Voivodeship.

The purpose of the present study was to build company survival models for individual poviats in Zachodniopomorskie. In the first stage, the Kaplan-Meier estimator was calculated and a test to verify the similarity of the survival function for the poviats was conducted. The poviats were classified into groups. Next, tables of company survival were built and the company liquidation intensity was analysed in individual groups of poviats. In the subsequent stage, the percentage of companies liquidated in the first and the second year of operation was determined in individual poviats and groups (stage III). Additionally, an analysis was performed of the correlation between the percentage of firms liquidated during the observation period and the number of registered entities per 10 thousand of population in the poviats (stage IV). This study used data from the registry of REGON related to companies established in the Zachodniopomorskie Voivodeship in 2009-2011 (21 poviats). The entities were observed till the end of 2013.

\section{Statistical data}

The article presents the results of the cohort analysis. The cohorts comprise the enterprises set up in the poviats of Zachodniopomorskie in 2009-2011 that were observed till the end of 2013. The information about the number of established and closed-down businesses is shown in Table 1, while Figure 1 shows the number of liquidated and censored (not liquidated till the end of the observation period) firms. Throughout 2009-2011, in Zachodniopomorskie, 59,587 firms were established. By the end of 2013, the number of liquidated firms reached 22,234 (37\%).

Table 1. The number of firms established in 2009-2011 and liquidated by the end of 2013 in the poviats of the Zachodniopomorskie Voivodeship

\begin{tabular}{|c|l|c|c|}
\hline \multirow{2}{*}{ NTS4 } & \multirow{2}{*}{ Poviat } & \multicolumn{2}{|c|}{ Number of firms } \\
\cline { 3 - 4 } & & established & liquidated \\
\hline 01 & białogardzki & 1485 & 623 \\
\hline 02 & choszczeński & 1389 & 572 \\
\hline
\end{tabular}




\begin{tabular}{|c|l|c|c|}
\hline \multirow{2}{*}{ NTS4 } & \multirow{2}{*}{ Poviat } & \multicolumn{2}{|c|}{ Number of firms } \\
\cline { 3 - 4 } & & established & liquidated \\
\hline 03 & drawski & 1381 & 499 \\
\hline 04 & goleniowski & 2638 & 1054 \\
\hline 05 & gryficki & 2415 & 1096 \\
\hline 06 & gryfiński & 2643 & 1005 \\
\hline 07 & kamieński & 1857 & 704 \\
\hline 08 & kołobrzeski & 3049 & 1112 \\
\hline 09 & koszaliński & 2088 & 826 \\
\hline 10 & myśliborski & 2070 & 789 \\
\hline 11 & policki & 3076 & 1054 \\
\hline 12 & pyrzycki & 1220 & 508 \\
\hline 13 & sławieński & 1788 & 773 \\
\hline 14 & stargardzki & 3983 & 1661 \\
\hline 15 & szczecinecki & 1968 & 814 \\
\hline 16 & świdwiński & 1102 & 450 \\
\hline 17 & wałecki & 1366 & 536 \\
\hline 18 & łobeski & 1059 & 464 \\
\hline 61 & Koszalin (city) & 3999 & 1304 \\
\hline 62 & Szczecin (city) & 17398 & 5795 \\
\hline 63 & Świnoujście (city) & 1613 & 595 \\
\hline & Voivodeship & $\mathbf{5 9 5 8 7}$ & $\mathbf{2 2 2 3 4}$ \\
\hline
\end{tabular}

Source: own study (REGON data)

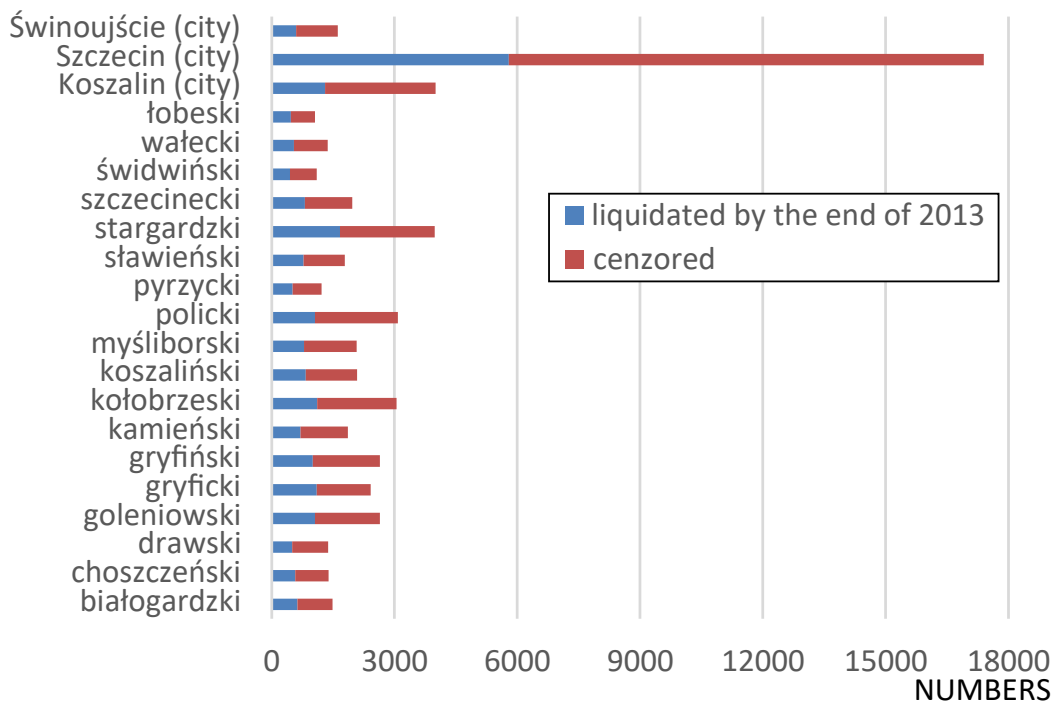

Figure 1. The number of firms established in 2009-2011, liquidated and censored in the poviats of the Zachodniopomorskie Voivodeship 


\section{Groups of poviats with similar survival functions}

A non-parametric firm survival model in the poviats of Zachodniopomorskie can be built by means of the Kaplan-Meier method (Product-Limit-Estimation), provided that we assume the presence of censored observations. In contrast to the survival tables, this method does not require grouping the observation times into class intervals. The firms' survival time is the realisation of the random variable $(T ; \delta)$ :

$$
T=\left\{\begin{array}{lll}
T_{z} & \text { for } & \delta=1 \\
T_{c} & \text { for } & \delta=0
\end{array},\right.
$$

where: $T_{z}$ - the survival time of a liquidated firm; $T_{c}$ - the survival time of a censored firm; $\delta$ - the random variable adopting 1 for a complete observation and 0 for a censored observation.

The Kaplan-Meier estimator can be calculated as (Kaplan, Meier, 1958; Markowicz, 2012):

$$
\hat{S}\left(t_{i}\right)=\prod_{t \leq t_{i}}\left(1-\frac{z_{i}}{n_{i}}\right) \text { for } i=1, . ., k,
$$

where: $t_{i}$ - the moment in which there was at least one event (firm liquidation), $z_{i}$ - the number of events at time $t_{i}$ (complete observations), $n_{i}-$ the number of units of observation at time $t_{i}$.

The Kaplan-Meier estimator is a function that is non-increasing, periodically constant, with leaps at random time points determined by complete observations (liquidation of at least one enterprise). The estimator adopts the values:

$$
\hat{S}\left(t_{i}\right)=\left\{\begin{array}{lll}
1 & \text { for } t_{0} \\
\prod_{t \leq t_{i}}\left(1-\frac{z_{i}}{n_{i}}\right) & \text { for } t_{1} \leq t \leq t_{k} \\
0 & \text { for } t>t_{k} & \text { when } \delta_{n}=1 \\
\text { undefined } & \text { for } t>t_{k} & \text { when } \delta_{n}=0
\end{array}\right.
$$

The initial value of the survival function is 1 and it decreases at subsequent points of time $t_{i}$ at which at least one analysed event has occurred. According to the literature, the statistical properties of the Kaplan-Meier estimator are regarded as good when the sample is large ${ }^{1}$. When using the Kaplan-Meier estimator, the

${ }^{1}$ The modification of the Kaplan-Meier estimator for small samples was proposed by Rossa, 2005. 
probability of survival can be estimated at any time. The statistical relevance of the differences in survival models built for groups can be measured with an adequate non-parametric statistical test, taking into consideration the presence of censored data. The hypothesis that the survival functions for groups are equal (Gehan, 1965; Klainbaum, Klein, 2005) is verified by means of the Gehan test, whose statistics are written (Namboodiri, Suchindran, 1987) as follows:

$$
G=\frac{W}{\sqrt{V}},
$$

where (Domański, Pruska, 2000; Domański et al., 2014):

$$
\begin{gathered}
W=\sum_{i=1}^{n_{1}} \sum_{j=1}^{n_{2}} U_{i j}, \\
U_{i j}=\left\{\begin{array}{lll}
-1 & \text { for } t_{i}<t_{j} & \text { or } t_{i} \leq t_{j}^{+} \\
0 & \text { for } t_{i}=t_{j} & \text { or } t_{i}^{+} \leq t_{j}^{+} \text {or } t_{i}^{+}<t_{j} \text { or } t_{j}^{+}<t_{i} \\
1 & \text { for } t_{i}>t_{j} & \text { or } t_{i}^{+} \leq t_{j}
\end{array}\right.
\end{gathered}
$$

where: $t_{i}$ - complete observations of the first group, $t_{j}$ - complete observations of the second group, $t_{i}^{+}-$censored observations of the first group, $t_{j}^{+}-$censored observations of the second group.

In order to distinguish the groups of Zachodniopomorskie poviats with similar firm survival times, the relevance of differences in the survival times of firms established in 2009-2011 in 21 poviats was examined. Kaplan-Meier estimators were calculated for each poviat and compared pair-wise. The groups were separated in such a way as to ensure that each of them contains poviats where the differences among survival time models were not statistically significant. For each pair of poviats, the hypothesis $H_{0}: S_{1}(t)=S_{2}(t)$ for each $t$ was tested. The differences were considered significant when $p \leq 0.05$. Therefore, each group contained only the poviats with similar survival functions. The functions in the poviats of one group can be significantly or irrelevantly different from the poviats in other groups. Moreover, the groups were ordered according to the decreasing probability of the analysed firms' survival over time. On the other hand, the poviats within the groups were ordered depending on the increasing number of similarities to the poviats in other groups. The groups are shown in Table 2. In keeping with the above scheme, five groups of poviats with similar firm survival time models were distinguished. The first group consisted of the following poviats: Koszalin (city), Szczecin (city) and policki (adjacent to Szczecin), where the probability of the analysed firms' survival in the successive months was the highest. Another group comprised a single 
poviat, i.e. the drawski poviat. The tests indicated the similarity of the survival function to some poviats in groups 1 and 3 . The remaining groups were characterised by increasingly faster declining survival functions. It needs to be noted that the last group, the gryficki poviat, had the lowest probabilities of survival in the successive months. The tests demonstrated the significance of the differences between the firm survival model in that poviat and the remaining poviats. The last column in Table 2 shows the test values for many samples designated for groups of multi-poviats. The results reveal a lack of significant differences in the survival function within the groups.

Table 2. Groups of poviats with a similar firms' duration model

\begin{tabular}{|c|c|c|c|c|}
\hline NTS4 & Poviat & $\begin{array}{c}\text { Numbers } \\
\text { of similarities } \\
\text { outside the } \\
\text { group }\end{array}$ & Group & $\begin{array}{c}\text { Test } \\
\text { (p-value) }\end{array}$ \\
\hline 61 & Koszalin (city) & 0 & \multirow{3}{*}{1} & \multirow{3}{*}{$\begin{array}{c}1.9565 \\
(0.3760)\end{array}$} \\
\hline 62 & Szczecin (city) & 1 & & \\
\hline 11 & policki & 2 & & \\
\hline 03 & drawski & 8 & 2 & \\
\hline 17 & wałecki & 1 & \multirow{9}{*}{3} & \multirow{9}{*}{$\begin{array}{c}6.4037 \\
(0.6021)\end{array}$} \\
\hline 08 & kołobrzeski & 2 & & \\
\hline 10 & myśliborski & 2 & & \\
\hline 15 & szczecinecki & 2 & & \\
\hline 16 & świdwiński & 2 & & \\
\hline 04 & goleniowski & 3 & & \\
\hline 06 & gryfiński & 3 & & \\
\hline 63 & Świnoujście (city) & 3 & & \\
\hline 07 & kamieński & 5 & & \\
\hline 13 & sławieński & 0 & \multirow{7}{*}{4} & \multirow{7}{*}{$\begin{array}{c}4.5315 \\
(0.6051)\end{array}$} \\
\hline 18 & łobeski & 0 & & \\
\hline 14 & stargardzki & 1 & & \\
\hline 12 & pyrzycki & 2 & & \\
\hline 02 & choszczeński & 4 & & \\
\hline 01 & białogardzki & 7 & & \\
\hline 09 & koszaliński & 8 & & \\
\hline 05 & gryficki & 0 & 5 & \\
\hline
\end{tabular}

Source: own study 


\section{Intensity of firms' liquidation}

The next stage of the analysis was the construction of cohort tables of firms' survival in individual poviats (21 areas). The tabular model was built for the three-month models (Markowicz, 2015). The enterprises that did not go into liquidation by the end of 2013 are considered censored. Based on the elements of the table, the intensity function of firm liquidation (hazard function) was analysed.

The estimator $\hat{\mathrm{h}}_{t}$ of intensity function is calculated as the ratio of the probability estimator of a firm's liquidation in the interval $(t, t+1)$ to the half of the sum of the estimators of the firm's probability to outlive beyond the intervals $(t, t+1)$ and $(t-1, t)$ (Balicki, 2006):

$$
\hat{h}_{t}=\frac{\hat{f}_{t}}{\left(\hat{S}_{t}+\hat{S}_{t-1}\right) / 2} \text {. }
$$

Many studies have confirmed that the intensity function of firms' liquidation adopts the inverted $U$-shape with a fixed maximum, which is in keeping with the theoretical learning model (Markowicz, 2012; Markowicz, 2016).

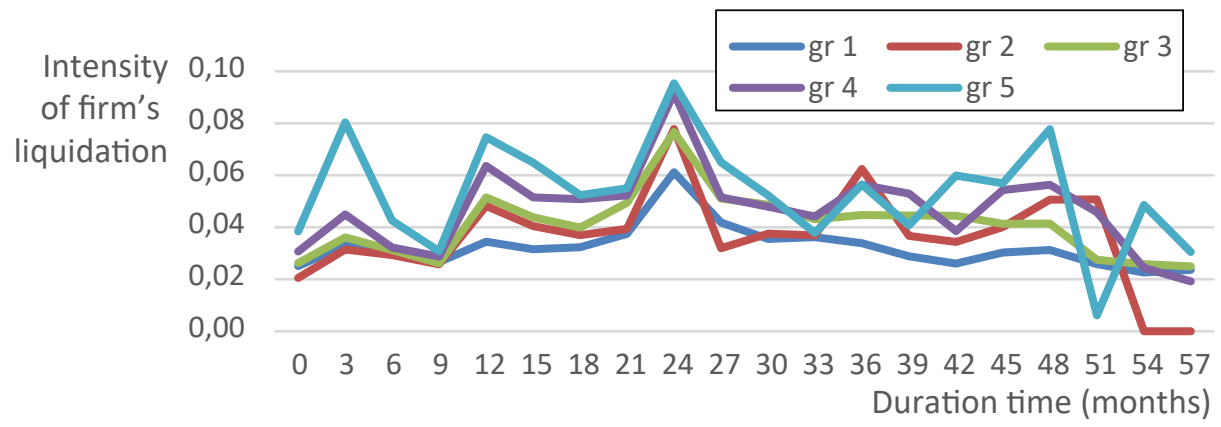

Figure 2. Estimation of the intensity of firms' liquidation

Source: own study

Figure 2 shows the intensity function of the analysed firms' liquidation for five groups of poviats. The functions of individual groups take the characteristic shape. The survival time is analysed in intervals (Figure $2-$ the beginning of the time interval). Having analysed the shape of the intensity function of firms' liquidation in individual groups of poviats built according to the survival models, the following observations were made:

1) the intensity function of firms' liquidation for group 1 takes the typical inverted $U$-shape with the maximum marked within 24-27 months; it adopts low values; 
2) passing from group 1 to group 5, we can observe a less and less distinct shape of the intensity function in the form of inverted $U$-shape, increasingly higher intensities of firms' liquidation and increasingly stronger fluctuations of this intensity over time.

\section{Liquidation of firms after 2 years of economic activity}

Between 2009 and 2011, in the Zachodniopomorskie Voivodeship, 59,587 enterprises were established. By the end of 2013, 37.3\% of them were closed down. In individual poviats, the percentage of liquidated firms was: $33.3 \%$ (group 1; in the poviats of $32.6 \%$ to $34.3 \%$ ), $36.1 \%$ (group 2; one poviat), $38.6 \%$ (group 3; in the poviats of $36.5 \%$ to $41.4 \%$ ), $41.7 \%$ (group 4 ; in the poviats of $39.6 \%$ to $43.8 \%$ ), $45.4 \%$ (group 5; one poviat). Thus, from group 1 to 5 , the share of liquidated firms was growing. The above-presented analysis of the intensity function revealed that the critical moment was the 24th month of activity. Later, the intensity of liquidations decreased. Therefore, the author determined the indicator of liquidation after 24 months of enterprise activity. The results are shown in Figure 3 (the indicator of liquidation after 1 year of activity was also calculated). In the voivodeship, $23.2 \%$ of firms were liquidated after 24 months of existence. Figure 3 shows the poviats by groups. The percentage of liquidated firms is growing; in successive groups, respectively: $19.7-20.5 \%$ (group 1), $21.7 \%$ (group 2), $22.4-24.8 \%$ (group 3), 25.7-28.3\% (group 4), and 31.1\% (group 5).

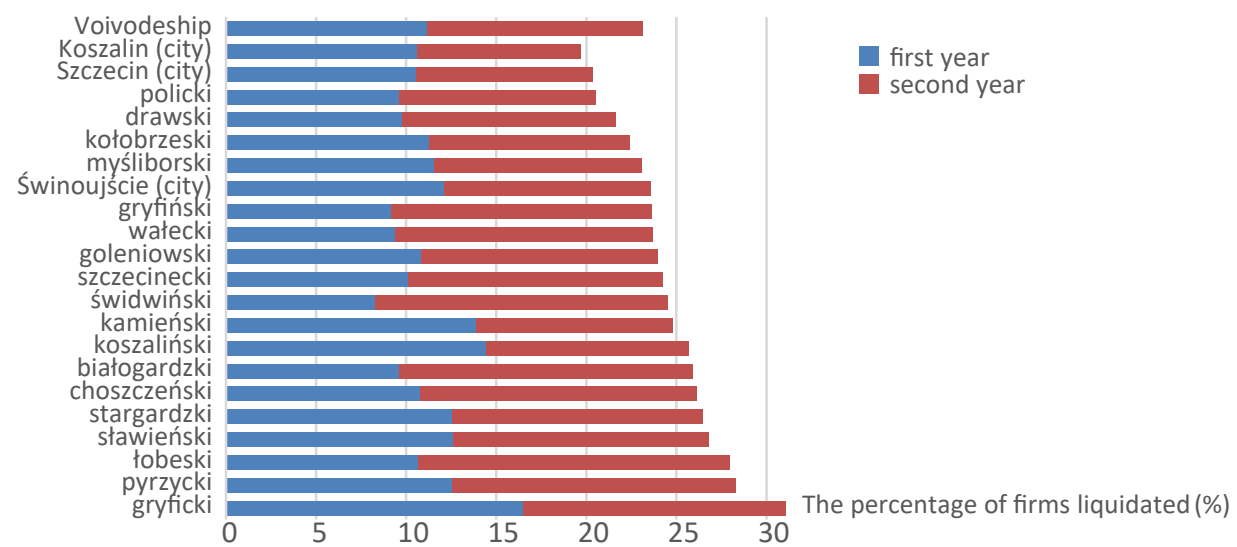

Figure 3. The percentage of firms liquidated after 2 years (also after 1 year) of economic activity

Source: own study 


\section{Liquidated firms vs operating enterprises}

The last stage of the study contains an analysis of the correlation between the number of firms established in 2009-2011 that were liquidated by the end of 2013 and the number of businesses existing in 2013 per 10 thousand residents in individual poviats. It seems that in the poviats with lower density of firms, the possibility for new start-ups to emerge and survive was bigger. The relationship between the examined variables is shown in Figure 4. The Pearson correlation coefficient was $-0.7008,(t=-4.2818 ; p=0.0002)$. Thus, it turns out that the more operating businesses per 10 thousand residents, the lower the percentage of liquidated firms. It was in the poviats with high density of businesses where new entities found their market niche. In Figure 4, the previously created groups of poviats are marked. Groups 1-5 are placed along the regression line starting from the lowest percentage of liquidations (with slight derogations).

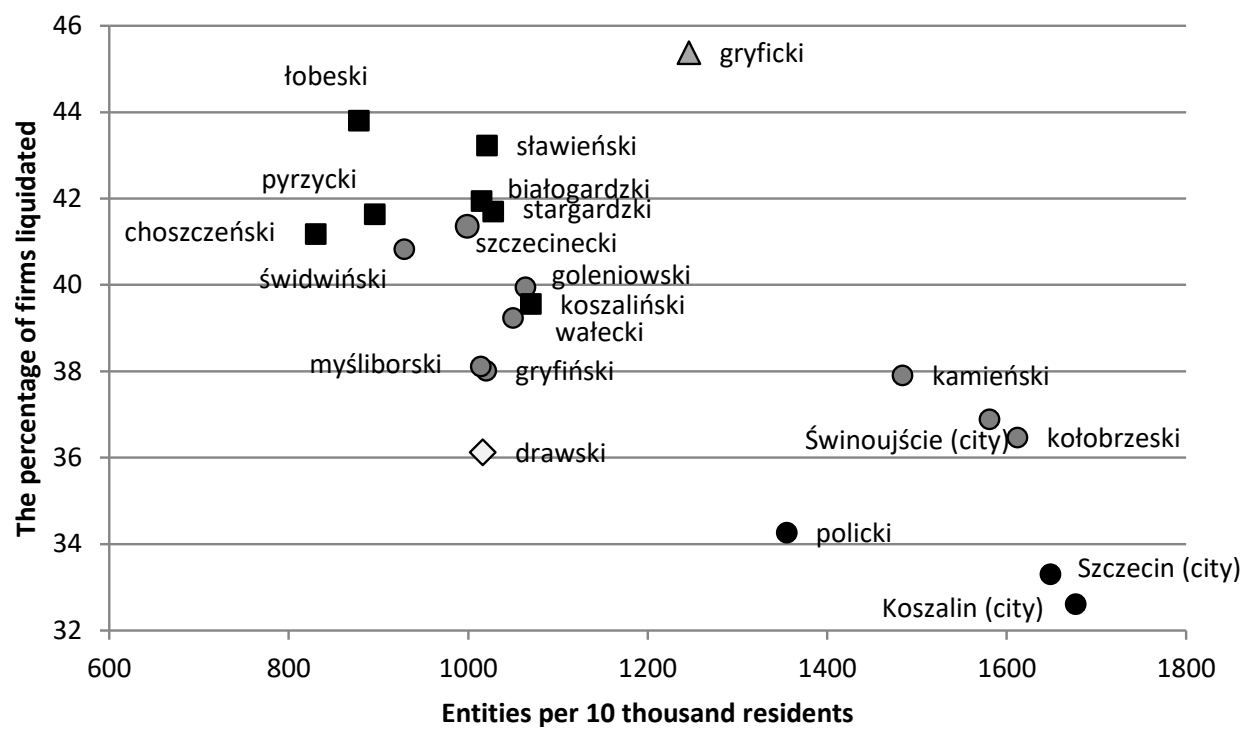

Figure 4. The percentage of firms liquidated and the number of entities per 10 thousand residents in the Zachodniopomorskie Voivodeship poviats

Source: own study 


\section{Conclusions}

The study results presented in this article reveal the differentiation of firm survival models in the poviats of the Zachodniopomorskie Voivodeship. Five groups of poviats were distinguished. The groups (from 1 to 5) were characterised by:

1) decreasing time to firms' liquidation (decreasing survival functions),

2) a less and less distinct shape of the intensity function (inverted $U$-shape),

3) growing intensity of firms' liquidation,

4) increasingly stronger fluctuations of intensity in time,

5) an increasingly higher percentage of enterprises liquidated during two years of activity,

6) decreasing density of firms accompanied by a growing percentage of liquidations.

The research has shown that a critical moment is the 24th month of operation. One of the reasons for the obtained rate of firms' liquidation may be the period of subsidised social security contributions (ZUS, 2014). Since 2005 start-up owners can pay significantly lower social security contributions for the first 24 months of operation, which definitely helps enterprises to survive. However, the failure of businesses after the period of subsidised contributions comes to an end suggests their weakness.

\section{References}

Balicki A. (2006), Analiza przeżycia i tablice wymieralności, PWE, Warszawa.

Domański Cz., Pruska K. (2000), Nieklasyczne metody statystyczne, PWE, Warszawa.

Domański Cz., Pekasiewicz D., Baszczyńska A., Witaszczyk A. (2014), Testy statystyczne w procesie podejmowania decyzji, Wydawnictwo Uniwersytetu Łódzkiego, Łódź.

Frątczak E., Gach-Ciepiela U., Babiker H. (2005), Analiza historii zdarzeń. Elementy teorii, wybrane przyktady zastosowań, SGH, Warszawa.

Gazińska M. (2003), Potencjat demograficzny w regionie. Analiza ilościowa, Wydawnictwo Naukowe Uniwersytetu Szczecińskiego, Szczecin.

Gehan E.A. (1965), A Generalized Two-SampleWilcoxon Test for Double-Censored Data, "Biometrika", vol. 52, no. 3-4, pp. 203-223.

Kaplan E.L., Meier P. (1958), Nonparametric Estimation from Incomplete Observations, "Journal of the American Statistical Association", vol. 53, no. 282, pp. 457-481.

Kleinbaum D.G., Klein M. (2005), Survival Analysis, Springer, New York.

Markowicz I. (2012), Statystyczna analiza żywotności firm, Wydawnictwo Naukowe Uniwersytetu Szczecińskiego, Szczecin.

Markowicz I. (2014), Business Demography - Statistical Analysis of Firm Duration, "Transformations in Business \& Economics", vol. 13, no. 2B (32B), pp. 801-817.

Markowicz I. (2015), Duration Analysis of Firms - Cohort Tables and Hazard Function, "International Journal of Business and Social Research", vol. 5, issue 11, pp. 36-47. 
Markowicz I. (2016), Tablice trwania firm w województwie zachodniopomorskim wedtug rodzaju działalności, [in:] K. Jajuga, M. Walesiak (eds.), "Taksonomia", no. 26, "Prace Naukowe UE we Wrocławiu", no. 426, pp. 108-117.

Namboodiri K., Suchindran C.M. (1987), Life Table Techniques and Their Applications, Academic Press Inc., New York.

Rossa A. (2005), Metody estymacji rozktadu czasu trwania zjawisk dla danych cenzurowanych oraz ich zastosowania, Wydawnictwo Uniwersytetu Łódzkiego, Łódź.

ZUS (2014), Ubezpieczenia społeczne i ubezpieczenie zdrowotne osób prowadzacych pozarolnicza działalność i osób z nimi wspótpracujących, http://www.zus.pl/pliki/poradniki/porad25. pdf [accessed: 20.08.2016].

\section{Zróżnicowanie modelu trwania firm w powiatach województwa zachodniopomorskiego}

Streszczenie: Celem przeprowadzonych badań była budowa modelu trwania firm dla poszczególnych powiatów województwa zachodniopomorskiego. Pierwszym etapem było oszacowanie estymatora Kaplana-Meiera oraz zastosowanie testu weryfikującego podobieństwo funkcji przeżycia dla powiatów. Utworzono grupy powiatów. Następny etap badań to budowa tablic trwania firm i analiza funkcji intensywności likwidacji firm w grupach powiatów. Następnie przedstawiono odsetek firm zlikwidowanych po dwóch latach działalności w poszczególnych powiatach (etap III). Przeprowadzono także analizę współzależności między odsetkiem zlikwidowanych w badanym okresie firm i liczbą zarejestrowanych podmiotów na 10 tys. ludności w powiatach (IV etap). W badaniu wykorzystano dane z rejestru REGON, dotyczące firm powstałych w województwie zachodniopomorskim w latach 2009-2011 (21 powiatów). Obserwacja trwała do końca 2013 roku. Wyniki badań pozwoliły wskazać na zróżnicowanie modeli trwania firm w powiatach województwa zachodniopomorskiego. Utworzono pięć grup powiatów i scharakteryzowano je.

Słowa kluczowe: model trwania firm, funkcja intensywności likwidacji firm, powiaty województwa zachodniopomorskiego

JEL: C10, C14, C41

\begin{tabular}{|l|l|}
\hline \multirow{2}{*}{ OPEN ACCESS } & $\begin{array}{l}\text { C by the author, licensee Łódź University - Łódź University Press, Łódź, Poland. } \\
\text { This article is an open access article distributed under the terms and conditions } \\
\text { of the Creative Commons Attribution license (C-BY } \\
\text { (http://creativecommons.org/licenses/by/3.0/) }\end{array}$ \\
\cline { 2 - 2 } & Received: 2016-12-28; verified: 2017-05-23. Accepted: 2017-09-28 \\
\hline
\end{tabular}

